\title{
COMMONSENSE CARDIOLOGY
}




\section{COMMONSENSE CARDIOLOGY}

Dr George Strube Dr Gillian Strube

General Practitioners,

Crawley, Sussex

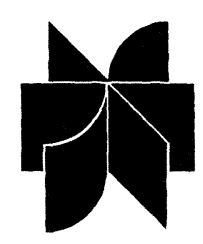

KLUWER ACADEMIC PUBLISHERS

DORDRECHT / BOSTON / LONDON 


\title{
Distributors
}

for the United States and Canada: Kluwer Academic Publishers, PO Box 358, Accord Station, Hingham, MA 02018-0358, USA

for all other countries: Kluwer Academic Publishers Group, Distribution Center, PO Box 322, $3300 \mathrm{AH}$ Dordrecht, The Netherlands

\section{British Library Cataloguing in Publication Data}

\author{
Strube, George \\ Commonsense cardiology. \\ 1. Medicine. Cardiology \\ I. Title II. Strube, Gillian \\ $616.1 ' 2$
}

ISBN-13:978-94-010-7055-3

Library of Congress Cataloging in Publication Data

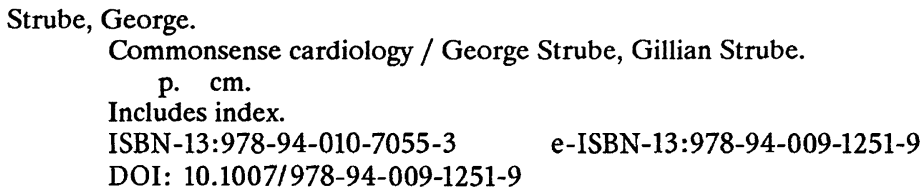

1. Cardiology. 2. Heart-Diseases. I. Strube, Gillian.

II. Title.

[DNLM: 1. Cardiology. 2. Heart-Diseases. WG 100 S927c]

RC681.S894 1988

616.1 '2-dc19

DNLM/DLC

for Library of Congress

\section{Copyright}

(C) 1989 by Kluwer Academic Publishers

Sof tcover reprint of the hardcover 1st edition 1989

All rights reserved. No part of this publication may be reproduced, stored in a retrieval system, or transmitted in any form or by any means, electronic, mechanical, photocopying, recording or otherwise, without prior permission from the publishers, Kluwer Academic Publishers BV, PO Box 17, 3300 AA Dordrecht, The Netherlands.

Published in the United Kingdom by Kluwer Academic Publishers, PO Box 55, Lancaster, UK.

Kluwer Academic Publishers BV incorporates the publishing programmes of D. Reidel, Martinus Nijhoff, Dr W. Junk and MTP Press. 


\section{Contents}

Preface vii

Part 1: THE BASICS 1

1.1 Introduction 2

1.2 Basic anatomy 4

1.3 Physiological models 8

1.4 Electrophysiology 31

$\begin{array}{ll}\text { Part 2: CARDIAC DRUGS } & 37\end{array}$

2.1 Introduction 38

2.2 Hazards, safety and effectiveness 39

2.3 Sorting out the drugs 46

Part 3: THE DIAGNOSTIC PROCESS 83

3.1 Introduction $\quad 84$

3.2 Clinical history 86

3.3 Sorting out the symptoms 90

3.4 Examination 102

3.5 Electrocardiology 113

3.6 Pathological tests and chest X-rays 136 
4.1 Introduction

4.2 Ischaemic heart disease

4.3 Heart failure

4.4 Essential hypertension

221

4.5 Arrhythmias

238

4.6 Valvular disease

256

4.7 Congenital heart disease

274

4.8 Bacterial endocarditis

278

4.9 Cardiomyopathies

282

4.10 Pulmonary embolism

285

4.11 Pregnancy

4.12 Care of the patient dying of heart disease

5.2 Risk factors and prevention

5.3 The role of the Primary Health Care Team

Index 


\section{Preface}

Cardiology embraces a number of different conditions and disease processes. Cardiovascular disease is now responsible for most of the deaths of adults, especially premature deaths, in the developed world.

The development of effective preventive measures, new drugs and surgical techniques makes it increasingly important to recognise those at risk, to diagnose accurately those suffering from disease and to prescribe, monitor and refer appropriately.

This book is intended to focus attention on the opportunities which family practice provides for this and to look at the need for a change in emphasis in approaching the problems.

The book is in five parts. Part 1 is a reminder of some of the basic principles, which are essential if sensible cardiology is to be practised. Part 2 is about cardiac drugs, their use, effectiveness and risks. Part 3 looks at the diagnostic process; it comprises the history, examination, investigation and referral of patients, who might have cardiac disease and also the drugs which are most likely to be used. Part 4 is devoted to specific conditions. In Part 5, we look at the need for prevention and consider how it may be tackled in general practice.

This is not a comprehensive textbook of cardiology. It is not intended for students. It is hoped that it may be useful to experienced doctors, struggling to provide a sound, sensible service in an environment of ever expanding technology.

\section{Acknowledgement}

We would like to thank Dr Richard Vincent, Consultant Cardiologist at the Royal Sussex County Hospital, Brighton, for his help, advice and limitless patience, particularly in choosing and providing the ECGs. He has given us much support and encouragement and contributed greatly to any merit the book may have. He is in no way responsible for its deficiencies. 